Int. J. Electrochem. Sci., 16 (2021) Article ID: 210718

International Journal of

ELECTROCHEMICAL

SCIENCE

www.electrochemsci.org

\title{
Mn(III) and Fe(III) Porphyrin Complexes as Electrocatalysts for Hydrogen Evolution Reaction: A comparative study
}

\author{
Monirah H Alzabny, Raoudha Soury, Khalaf M Alenezi* \\ Department of Chemistry, College of Science, University of Ha'il, Ha'il, Kingdom of Saudi Arabia. \\ "E-mail: k.alenezi@uoh.edu.sa
}

doi: $10.20964 / 2021.07 .24$

Received: 11 March 2021 / Accepted: 20 April 2021 / Published: 31 May 2021

In the present work, we carried out comparative studies on electrochemical reduction of proton to molecular hydrogen, i.e. $2 \mathrm{H}^{+}+2 \mathrm{e} \rightarrow \mathrm{H}_{2}$ using meso-tetrakis-(tetraphenyl)porphyrin iron(III) chloride $[\mathrm{Fe}(\mathrm{TPP}) \mathrm{Cl}]$ and meso-tetrakis(phenyl)porphyrin manganese(III) chloride [Mn(TPP)Cl] as electrocatalysts. Acetic acid $\left(\mathrm{CH}_{3} \mathrm{COOH}\right)$ was used as the proton source. Results suggest that the reduction of $\mathrm{CH}_{3} \mathrm{COOH}$ on the surface of vitreous carbon electrode $(\mathrm{Ep}=-1.8 \mathrm{~V}$ vs. $\mathrm{Ag} / \mathrm{AgCl}$ in $\left.\left[\mathrm{Bu}_{4} \mathrm{~N}\right]\left[\mathrm{BF}_{4}\right]-\mathrm{DMF}\right)$ shifts to lower negative values in the presence of $[\mathrm{Fe}(\mathrm{TPP}) \mathrm{Cl}]$ and $[\mathrm{Mn}(\mathrm{TPP}) \mathrm{Cl}](-$ 1.6 and $-1.3 \mathrm{~V}$, respectively vs. $\mathrm{Ag} / \mathrm{AgCl}$ ). Analysis of peak current values indicated that $[\mathrm{Fe}(\mathrm{TPP}) \mathrm{Cl}]$ was more active $(6 \mathrm{x})$ as compared to $[\mathrm{Mn}(\mathrm{TPP}) \mathrm{Cl}]$. However, the $[\mathrm{Mn}(\mathrm{TPP}) \mathrm{Cl}]$-catalyzed reduction process more swiftly (the potential is more positive than $+30 \mathrm{mV}$ ).

Keywords: Electrocatalysis; hydrogen; iron, manganese complex, porphyrin

\section{FULL TEXT}

(C) 2021 The Authors. Published by ESG (www.electrochemsci.org). This article is an open access article distributed under the terms and conditions of the Creative Commons Attribution license (http://creativecommons.org/licenses/by/4.0/). 